\title{
Menumbuhkan Jiwa Enterpreneurship Mahasiswa STT Real Batam Melalui Kegiatan PKM Tahu Tempe Sebagai Jembatan Pewartaaan Injil
}

\author{
Fredy Simanjuntak*1, Mangiring Tua Togatorop², Ardianto Lahagu², Roy Martin \\ Simanjuntak ${ }^{4}$, Stefanus Meo Nekin ${ }^{5}$ \\ 1,2,5 Prodi Teologi, STT REAL Batam \\ ${ }^{3}$ Prodi PAK, STT REAL Batam \\ ${ }^{4}$ Prodi Teologi, STAK Teruna Bhakti \\ fredygrace@gmail.com
}

\begin{abstract}
This article discusses the Creativity Program initiated by the Theology Study Program with STT Real Batam students to take advantage of their free time to cultivate the entrepreneurial spirit of students through the skills of making tofu and tempeh. This was initially motivated by daily needs in the dormitory so that students could also eat simple, everyday foods that are no less healthy and beneficial for the body. The implementation method for this PkM program is by visiting one of the tofu-tempe production centers in Batu Aji. The purpose of the activity is to provide skills to students so as to foster an entrepreneurial spirit for STT Real Batam students. From the results of the evaluation, it was noted that he had attended several trainings from theory to practice. Students are motivated to develop such training in the campus environment. The implementation of this PKM is very useful to increase student creativity so that the production of tofu and tempeh can be used as a medium for Micro, small and medium enterprises and at the same time to complement the daily food needs of the hostel Keywords: Student Creativity Program, STT Real Batam: Business, Production, Tofu-Tempe During the Pandemic
\end{abstract}

\begin{abstract}
Abstrak
Artikel ini membahas tentang Program Kreativitas yang digagas oleh Prodi Teologi dengan mahasiswa STT Real Batam untuk memanfaatkan masa luang untuk menumbuhkan jiwa enterpreneuship mahasiswa melalui keterampilan pembuatan tahu dan tempe. Hal ini awalnya dimotivasi kebutuhan sehari-hari di asrama supaya mahasiswa pun dapat mengkomsi makanan sederhana sehari-hari yang tak kalah sehat dan bermanfaat bagi tubuh. Metode pelaksanaan pada program PkM ini yaitu dengan mengunjungi salah satu pusat produksi tahutempe di Batu Aji. Tujuan kegiatan adalah untuk memberikan meningkatkan keterampilan kepada mahasiswa sehingga menumbuhkan jiwa enterpreneurship bagi mahasiswa STT Real Batam. Dari hasil evaluasi, tercatat selama mengikuti beberapa kali pelatihan dari teori sampai praktek. Mahasiswa termotivasi untuk mengembangkan pelatihan pembuatan tersebut di lingkungan kampus. Pelaksanaan PKM ini sangat berguna untuk meningkatkan kreativitas mahasiswa untuk ditambah hasil produksi tahu dan tempe dapat dijadikan sarana UMKM dan sekaligus untu melengkapi keperluan makanan asrama sehari-hari.

Kata kunci: Program Kreativitas Mahasiswa, STT Real Batam: Usaha, Produksi, tahu-tempe Di masa Pandemi
\end{abstract}

\section{PENDAHULUAN}

Tahu dan tempe merupakan produk makanan favorit dan cukup populer popular di masyarakat Indonesia. Selain sebagai cemilan makanan ringan tahu dan tempe juga dikomsumsi sebagai lauk pauk pendamping nasi. Tahu dan tempe menjadi makanan yang sangat diminati oleh masyarakat Indonesia karena rasanya enak dan harganya juga relatif murah. Selain dikenal karena kelezatannya dalam makanan ini terkandung beberapa nilai gizi, seperti mineral, protein, karbohidrat, lemak, kalori, fosfor, dan vitamin B-kompleks. Tahu dan 
tempe juga kerap dijadikan salah satu menu diet rendah kalori karena kandungan hidrat arangnya yang rendah. ${ }^{1}$

Dalam beberapa tahun terakhir berbagai tantangan semakin kompleks. Tantangan dunia Pendidikan teologi tidak lagi sebatas menjadi tenaga professional, namun juga seyogiyanya berdampak pada masyarakat. Saat ini institusi-institusi Pendidikan sedang berbenah untuk meningkatkan jiwa kewirausahaan di sekolah masing-masing yang relevan untuk mendukung program pemerintah. Jika lini Pendidikan secara umum tidak absen dalam kegiatan kewirausahaan ini, sewajarnya Perguruan Tinggi Keagamaan Kristen seperti Sekolah Tinggi Teologipun harusnys tidak ketinggalan dengan keterampilan manajemen dan kewairausahaan pula. Guna memenuhi kualifikasi itu Sekolah Tinggi Teologia (STT) Real Batam, terutama Prodi Teologi \& PAK menggagas konsep kreativitas bersama mahasiswa dalam mengembangkan jiwa entrepreneurship muda. Para calon pendeta dan Pendidik agama Kristen harus dibekali bukan saja ilmu teologi dan Pendidikan dalam kelas tapi juga materi kewirausahaan dan penguasaan teknologi kekinian.

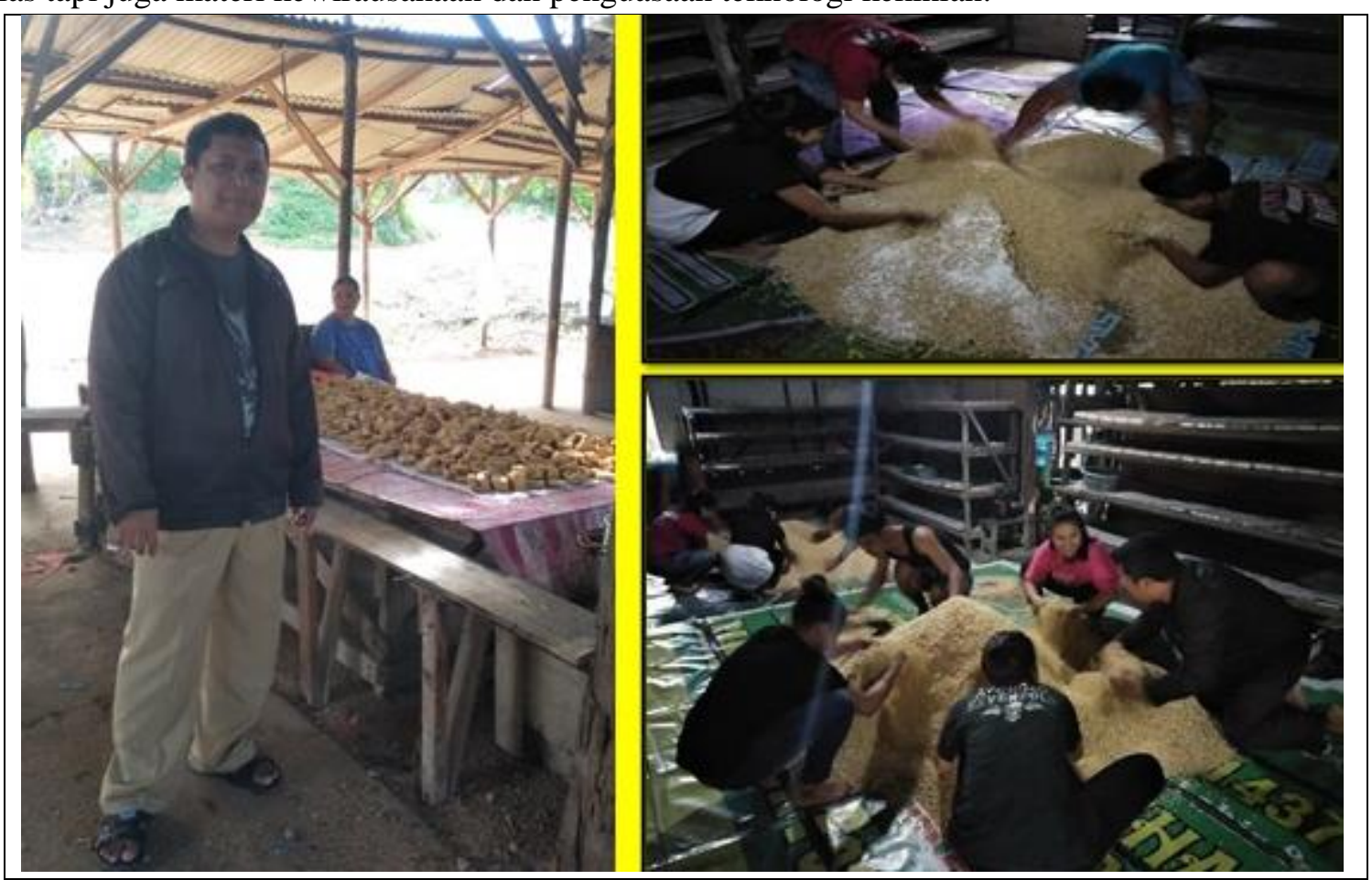

Gambar 1. Mahasiswa STT Real Batam Magang Pembuatan Tahu \& Tempe

Program kreativitas ini digagas supaya para mahasiswa dan mahasiswi bermental wiraswasta dan memiliki motivasi yang kuat, di STT Real sendiri diajarkan matakuliah entrepreneur yang diselingi dengan praktik projek di akhir perkuliahan. walau sebatas teori saja dan seminar ini untuk lebih menguatkan. Saat ini STT Real sendiri memiliki 8 prodi dengan jumlah mahasiswa mencapai 900 mahasiswa. Dalam hal kewirausahaan sudah banyak perguruan tinggi yang sukses memasarkan Program kreativitas mahasiswa menjadi andalan dalam kewirausahaan. Sebenarnya, di negara-negara maju hal ini bukan hal baru. Berkaca pada kesuksesan negara maju seperti amerika dan eropa yang hampir seluruh perguruan tingginya menyisipkan materi entrepreneurship dihampir setiap mata kuliahnya, negara-negara di asia seperti jepang, singapura dan malaysia juga menerapkan materimateri entrepreneurship minimal di dua semester. Itulah yang menjadikan negara-negara tetangga kita

${ }^{1}$ Citra Perdani Utami, Sukma Ayu Fitrianingrum, and Kristinah Haryani, "Pemanfaatan Iles-Iles (Amorphophallus Oncophylus) Sebagai Bahan Pengenyal Pada Pembuatan Tahu," Jurnal Teknologi Kimia dan Industri 1, no. 1 (2012): 79-85. 
tersebut menjadi negara maju dan melakukan lompatan panjang dalam meningkatkan pembangunan negaranya. ${ }^{2}$

\section{Rincian Modal Awal}

\begin{tabular}{|l|l|l|l|}
\hline \multicolumn{1}{|c|}{ Nama Alat } & \multicolumn{1}{|c|}{ Jumlah } & \multicolumn{1}{c|}{ Harga Total } & \multicolumn{1}{c|}{ Fungsi } \\
\hline Kompor dan Gas & 1 Buah & (milik asrama) & Untuk Memasak \\
\hline Wajan & 1 Buah & (milik asrama) & Untuk Menggoreng \\
\hline Baskom & 1 Buah & (milik asrama) & Untuk Tempat Mencampur Bahan \\
\hline Sendok Pengaduk & 2 Buah & (milik asrama) & Untuk Mengaduk \\
\hline Panci & 1 Buah & (milik asrama) & Untuk Merebus sari kedelai \\
\hline Blender & 2 Buah & (milik asrama) & $\begin{array}{l}\text { Untuk Menghaluskan kedelai dan } \\
\text { bumbu }\end{array}$ \\
\hline Cetakan tahu & 1 Buah & (milik asrama) & Untuk Mencetak Tahu \\
\hline Ember Besar & 1 Buah & (milik asrama) & Untuk Tempat sari kacang kedelai \\
\hline Kain & 3 Buah & Rp.30.000 & $\begin{array}{l}\text { Untuk Cetakan Tahu dan Untuk } \\
\text { Menyaring sari kedelai }\end{array}$ \\
\hline Mika Kotak mini & 50 Buah & Rp.15.000 & Untuk Kemasan \\
\hline Garpu Plastik & 4Bungkus & Rp.15.000 & Untuk Kemasan \\
\hline \multicolumn{1}{|c|}{ Total } & & & Rp 60.000 \\
\hline
\end{tabular}

\section{Sumber dana}

Sumber pendanaan berasal dari koperasi STT Real Batam. Diharapkan melalui program koperasi ini akan lahir banyak produk usaha mikro yang diprakarsai olah mahasiswa bekerjasama dengan koperasi dan prodi.

\section{Jadwal Kegiatan}

\begin{tabular}{|c|c|c|c|c|c|c|c|}
\hline No & & \multicolumn{6}{|c|}{ Waktu } \\
\hline & Uraian Kegiatan & Bulan I & Bulan II & $\begin{array}{l}\text { Bulan } \\
\text { III }\end{array}$ & \begin{tabular}{|l} 
Bulan \\
IV
\end{tabular} & Bulan V & $\begin{array}{l}\text { Bulan } \\
\text { VI }\end{array}$ \\
\hline 1 & Survei pabrik tahu dan tempe & & & & & & \\
\hline 2 & $\begin{array}{l}\text { Pembelian alat-alat yang akan } \\
\text { diperlukan }\end{array}$ & & & & & & \\
\hline 3 & Pengajuan peminjaman alat & & & & & & \\
\hline
\end{tabular}

${ }^{2}$ Heri Kuswara, "Strategi Perguruan Tinggi Mewujudkan Entrepreneurial Campus," Badan Riset Dan Inovasi Nasional Republik Indonesia (Jakarta, February 2012), brin.go.id/strategi-perguruan-tinggimewujudkan-entrepreneurial-campus/. 


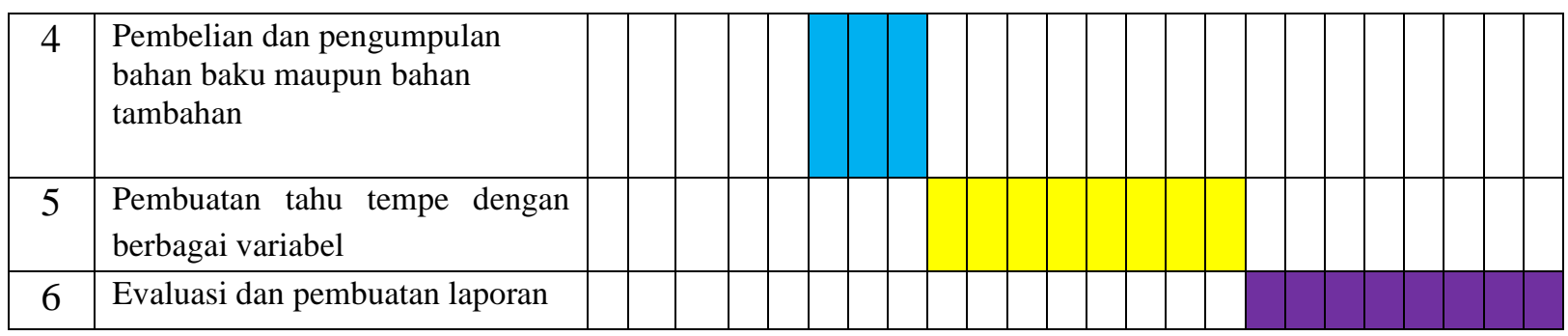

\section{Tujuan Kegiatan}

1. Meningkatkan ketermpilan mahasiswa dalam pembuatan tahu-tempe mandiri

2. Meningkatkan semangat dan motivasi mahasiswa dalam berwirausaha

3. Peningkatan SDM Mahasiswa.

4. Memberikan paradigma baru tentang pentingnya kewirausahaan bagi mahasiswa

5. Mengarahkan mindset mahasiswa menjadi seorang yang berjiwa entrepreneurship.

\section{Manfaat Kegiatan}

1. Diharapkan melalui kegiatan ini, kacang kedelai khususnya tahu-tempe dapat dimanfaatkan secara maksimal sehingga dapat meningkatkan nilai ekonomisnya dengan dihasilkan barang komersil

2. Meningkatkan pengetahuan mahasiswa STT Real Batam akan potensi peluang usaha yang memiliki prospek yang baik dan dapat meningkatkan kesejahteraan.

3. Meningkatkan partisipasi mahasiswa dalam mendukung UKKM Institusi STT Real Batam

4. Membuka peluang kerjasama usaha khususnya untuk mahasiswa/alumni.Dengan program kerjasama ini diharapkan mahasiswa terutama dapat menganalisa dan mengamati bentuk usaha nyata sehingga mempunyai gambaran ketika kelak berwirausaha.

5. Mewujudkan pembentukan unit usaha yang dikelola oleh mahasiswa STT Real Batam.

\section{Tahapan Kegiatan}

\begin{tabular}{|l|l|l|}
\hline No & \multicolumn{1}{|c|}{ Prose Pembuatan Tahu } & \multicolumn{1}{c|}{ Proses Pembuatan Tempe } \\
\hline $\mathbf{1}$ & $\begin{array}{l}\text { Melakukan proses pemilihan bahan baku tahu dan } \\
\text { tempe dengan menyrotir keledai yang memiliki } \\
\text { klualitas bagus menggunakan tampi/tampah }\end{array}$ & $\begin{array}{l}\text { Biji kedele yang telah di pilih/di bersihkan dari } \\
\text { kotoran, dicuci dengan air PDAM atau air sumur } \\
\text { yang bersih selama 1 jam. }\end{array}$ \\
\hline $\mathbf{2}$ & $\begin{array}{l}\text { Mencuci kedelai, kemudian dan direndam dalam } \\
\text { air hangat kurang lebih selama 6 sampai 12 jam. } \\
\text { Hal ini dilakukan sampai tekstur kedelai mudah } \\
\text { diolah. Usahakan seluruh kedelai tenggelam. } \\
\text { Dalam proses perendaman ini kedelai akan } \\
\text { mengembang. }\end{array}$ & $\begin{array}{l}\text { Setelah bersih kedele di rebus dalam air selama } 2 \\
\text { jam. }\end{array}$ \\
\hline $\mathbf{3}$ & $\begin{array}{l}\text { Selesai direndam kacang kedelai dibersihkan } \\
\text { dengan cara dicuci berkali kali. Usahakan kedelai } \\
\text { sebersih mungkin untuk menghindari kedelai } \\
\text { cepat masam. }\end{array}$ & $\begin{array}{l}\text { Kemudian direndam 12 jam dalam air panas/hangat } \\
\text { bekas air perebusan dengan maksud supaya kedele } \\
\text { mengembang. }\end{array}$ \\
\hline $\mathbf{4}$ & $\begin{array}{l}\text { Untuk selanjutnya dihancurkan sampai halus. } \\
\text { biasanya menggunakan gilingan atau kalau yang } \\
\text { dibuat sedikit bisa juga menggunakan blender. } \\
\text { Tambahkan air sedikit-demi sedikit sehingga } \\
\text { kedelainya berbentuk bubur. }\end{array}$ & $\begin{array}{l}\text { Berikutnya di rendam dalam air dingin selama } 12 \\
\text { jam. }\end{array}$ \\
\hline $\mathbf{5}$ & $\begin{array}{l}\text { Sari kedelai disaring sedikit demi sedikit sampai } \\
\text { ampas kedelai tidak tersisa lagi. Proses ini } \\
\text { biasanya dilakukan berkali-kali agar air kedelai } \\
\text { dapat dibuat menjadi tahu yang halus. }\end{array}$ & $\begin{array}{l}\text { Setelah 24 jam seperti butir 3 dan butir } 4 \text { diatas, } \\
\text { kedele di cuci/dikuliti (dikupas). }\end{array}$ \\
\hline
\end{tabular}




\begin{tabular}{|c|c|c|}
\hline 6 & $\begin{array}{l}\text { Bubur kedelai dimasak pada suhu 70-80 derajat } \\
\text { (biasanya ditandai dengan gelembung kecil yang } \\
\text { muncul pada kedelai yang dimasak). Ingat untuk } \\
\text { menjaga agar kedelai jangan sampai mengental. }\end{array}$ & $\begin{array}{l}\text { Setelah di kupas, direbus untuk membunuh bakteri } \\
\text { yang kemungkinan tumbuh selama perendaman. }\end{array}$ \\
\hline 7 & $\begin{array}{l}\text { Kemudian, tunggu sampai uap panasnya } \\
\text { menghilang. Saring bubur kedelai tersebut, sambil } \\
\text { diaduk secara perlahan. Tambahkan bahan } \\
\text { pembuat tahu (batu tahu atau asam cukup) dan } \\
\text { aduk rata. Proses ini akan menghasilkan endapan } \\
\text { tahu (gumpalan). Endapan siap untuk di press. }\end{array}$ & $\begin{array}{l}\text { Kedele di ambil dari dandang, letakkan di atas } \\
\text { tampah dan diratakan tipis-tipis. Biarkan dingin } \\
\text { sampai permukaan keping kedele kering dan airnya } \\
\text { menetes habis. }\end{array}$ \\
\hline 8 & $\begin{array}{l}\text { Selanjutnya adonan tahu dalam cetakan } \\
\text { dikempa/dipress agar air yang terkandung di } \\
\text { dalam adonan tahu tersebut dapat terperas habis } \\
\text { tak tersisa untuk menekan ampas supaya } \\
\text { kandungan airnya benar-benar habis. }\end{array}$ & $\begin{array}{l}\text { Kemudian di campur dengan laru (ragi } 2 \% \text { ) guna } \\
\text { mempercepat pertumbuhan jamur. Proses mencampur } \\
\text { kedele dengan ragi memakan waktu sekitar } 20 \text { menit. } \\
\text { Tahap peragian (fermentasi) adalah kunci } \\
\text { keberhasilan atau tidaknya membuat tempe kedele. }\end{array}$ \\
\hline 9 & $\begin{array}{l}\text { Setelah itu adonan tahu tersebut sudah dapat } \\
\text { dipotong-potong sesuai ukuran yang diinginkan }\end{array}$ & $\begin{array}{l}\text { ila campuran bahan fermentasi kedele sudah rata, } \\
\text { kemudian dicetak pada loyang atau cetakan kayu } \\
\text { dengan lapisan plastik atau daun yang akhirnya di } \\
\text { pakai sebagai pembungkus. Sebelumnya, plastik di } \\
\text { lobangi/ditusuk-tusuk. Maksudnya ialah untuk } \\
\text { memberi udara supaya jamur yang tumbuh berwarna } \\
\text { putih. Proses percetakan/pembungkus memakan } \\
\text { waktu } 3 \text { jam. }\end{array}$ \\
\hline 10 & $\begin{array}{l}\text { Dan tahupun sudah jadi dan siap untuk } \\
\text { dikomsumsi/dipasarkan }\end{array}$ & $\begin{array}{l}\text { Campuran kedele yang telah dicetak dan diratakan } \\
\text { permukaannya di hamparkan di atas rak dan } \\
\text { kemudian ditutup selama } 24 \text { jam. }\end{array}$ \\
\hline 11 & & $\begin{array}{l}\text { Setelah } 24 \quad \text { jam tutup di buka dan } \\
\text { didinginkan/diangin-anginkan selama } 24 \text { jam. Setelah } \\
\text { ini campuran kedele telah menjadi tempe siap }\end{array}$ \\
\hline 12 & & $\begin{array}{l}\text { Untuk tahan lama, tempe yang misalnya akan } \\
\text { menjadi produk ekspor dapat di bekukan dan dikirim } \\
\text { ke luar negeri di dalam peti kemas pendingin. }\end{array}$ \\
\hline
\end{tabular}

\section{Metode Penelitian}

Waktu dan tempat penelitian yaitu pembuatan tahu dilaksanakan salah satu pusat produksi tahu-tempe di Batu Aji pengembanganya kemudian dikerjakan di asrama mahasiswa STT Real Sukajadi Batam.Waktu penelitian dilaksanakan pada bulan 3 Maret - 10 Juni 2020. Alat yang digunakan adalah kompor gas, panci, sendok, baskom, timbangan, gelas ukur, corong, kain belacu, blender, pisau, cetakan. Bahan yang digunakan adalah kacang kedelai, jeruk nipis, belimbing wuluh dan air, garam cuka dan ragi.

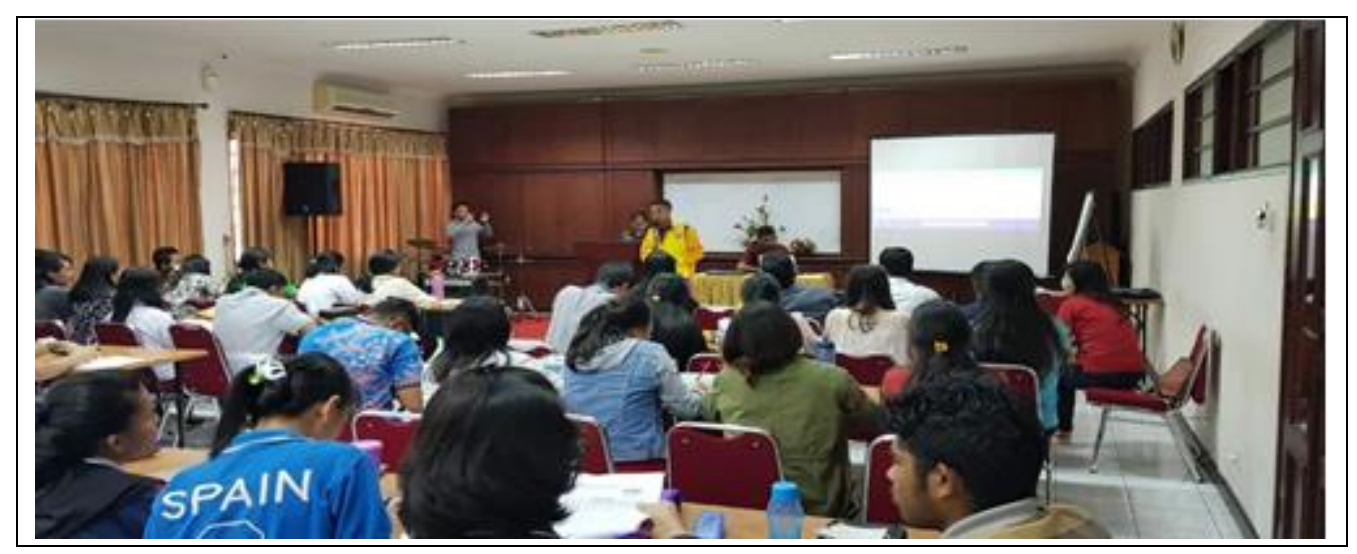

Gambar 2. Mahasiswa Mensosialisasikan Teori Pembuatan Tahu \& Tempe di Kelas 


\section{HASIL DAN PEMBAHASAN \\ Menumbuhkan Jiwa Enterpreneurship Mahasiswa}

Minat Masyrakat Indonesia untuk berwirausaha masih sangat rendah, termasuk pada lulusan perguruan tinggi. Umumnya mereka lebih dipersiapkan menjadi pencari kerja ketimbang pencipta lapangan kerja. Hal ini lebih jauh dipaparkan oleh Wardoyo, terkait kondisi tersebut di atas didukung pula oleh kenyataan bahwa sebagian besar lulusan Perguruan Tinggi adalah lebih sebagai pencari kerja daripada pencipta lapangan pekerjaan. ${ }^{3}$

Menurut McClelland dalam Tony Wijaya menngatakan suatu negara akan maju jika terdapat entrepreneur sedikitnya sebanyak $2 \%$ dari jumlah penduduk. ${ }^{4}$ Dilansir Global Entrepreneurship Monitor pada tahun 2005, Negara Singapura memiliki wirausahawan sebanyak 7,2 \% dari jumlah penduduk, sedangkan Indonesia hanya memiliki wirausawahan sebanyak 0,18 persen dari jumlah penduduk, tidak heran jika pendapatan perkapita negara singa tersebut puluhan kali lebih tinggi dari Indonesia. ${ }^{5}$

Walaupun jiwa wirausahawan diperoleh sejak lahir sebagai bakat, namun jika tidak diasah melalui belajar dan dimotivasi dalam proses pembelajaran tentu akan tidak berkembang, dan untuk mempertajam minat dan kemampuan wirausahawan perlu ditumbuh-kembangkan melalui proses belajar dan pembelajaran. ${ }^{6}$ Hal lain yang mungkin dapat mendorong mahasiswa untuk berintensi pada kewirausahaan adalah memunculkana figur-figur yang bisa menjadi role model bagi mereka selama mendapatkan pendidikan kewirausahaan. Role model ini dapat terbentuk live model yaitu seseorang yang secara langsung menampilkan perilaku, atau symbolic model yaitu seseorang atau perilaku yang muncul secara tidak langsung atau melalui suatu media. ${ }^{7}$

Selain melalui proses "modelling" ini, seharusnya mahasiswa juga dapat mempelajari tentang berwirausaha melalui pengalaman secara langsung melalui praktek-praktek yang diadakan pada saat mengikuti mata kuliah kewirausahaan tersebut. Pemagangan dan role model memiliki pengaruh yang sangat kuat untuk mendorong peserta didik untuk kemudian menjadi wirausaha. Karena menurut Fazio \& Zanna (dalam Franzoi, 1996) bahwa sikap yang terbentuk melalui pengalaman langsung akan lebih kuat daripada yang terbentuk tanpa pengalaman.

Pelaksanaan pendidikan kewirausahaan bukan diajarkan secara parsial menjadi sebuah mata pelajaran melainkan diintegrasikan pada seluruh mata pelajaran, pendidikan kewirausahaan juga ditanamkan melalui school's operational culture atau pembudayaan pendidikan kewirausahaan dalam kegiatan di sekolah. ${ }^{8}$ Kewirausahaan sebagai pendekatan organisasi dan manajemen yang memungkinkan seseorang merespon suatu masalah dan memecahkannya dengan inisiatif sendiri dalam situasi apa pun. ${ }^{9}$

Proses pendidikan di Indonesia tidak dapat dipisahkan dari kegiatan belajar mengajar di dalam sebuah institusi yang disebut dengan sekolah. Faktor penting dalam kegiatan pembelajaran adalah

\footnotetext{
${ }^{3}$ Wardoyo, "Pengaruh Pendidikan Dan Karakteristik Kewirausahaan Terhadap Intensi Berwirausaha Mahasiswa Pada Perguruan Tinggi Swasta Di Jakarta," in Seminar Nasional Kewirausahaan Dan Inovasi Bisnis II 2012 (Jakarta: Universitas Tarumanagara, 2012).

4 Tony Wijaya, "Kajian Model Empiris Perilaku Berwirausaha UKM DIY Dan Jawa Tengah,” Jurnal Manajemen dan Kewirausahaan 10, no. 2 (2008): 93-104.

${ }^{5}$ Ibid.

${ }^{6}$ Wardoyo, "Pengaruh Pendidikan Dan Karakteristik Kewirausahaan Terhadap Intensi Berwirausaha Mahasiswa Pada Perguruan Tinggi Swasta Di Jakarta."

${ }^{7}$ J. E Ormrod, Human Learning, 3rd ed. (Upper Saddle River, New Jersey: Merrill Prentice Hall, 1999).

${ }^{8}$ Jaana Seikkula-Leino et al., "Promoting Entrepreneurship Education: The Role of the Teacher?," Education + Training 52, no. 2 (March 16, 2010): 117-127, https://www.emerald.com/insight/content/doi/10.1108/00400911011027716/full/html.

${ }^{9}$ O N Ememe, S C Ezeh, and C A Ekemezie, "The Role of Head-Teacher in The Development of Entrepreneurship Education In Primary Schools," Journal of Social Sciences and Humanities 2, no. 1 (2013): $242-249$.
} 
materi pelajaran serta pengalaman yang diperoleh melalui proses tersebut. ${ }^{10}$ Fiet menjelaskan bahwa dalam proses pembelajaran seorang guru harus mengembangkan teori tentang kewirausahaan, teori yang disampaikan kepada peserta didik bukan sembarang teori, melainkan teori yang sarat akan kegiatan learning by doing. Pembelajaran yang menekankan pada learning by doing dapat mempercepat pemahaman dan penguasaan materi kewirausahaan oleh peserta didik. ${ }^{11}$

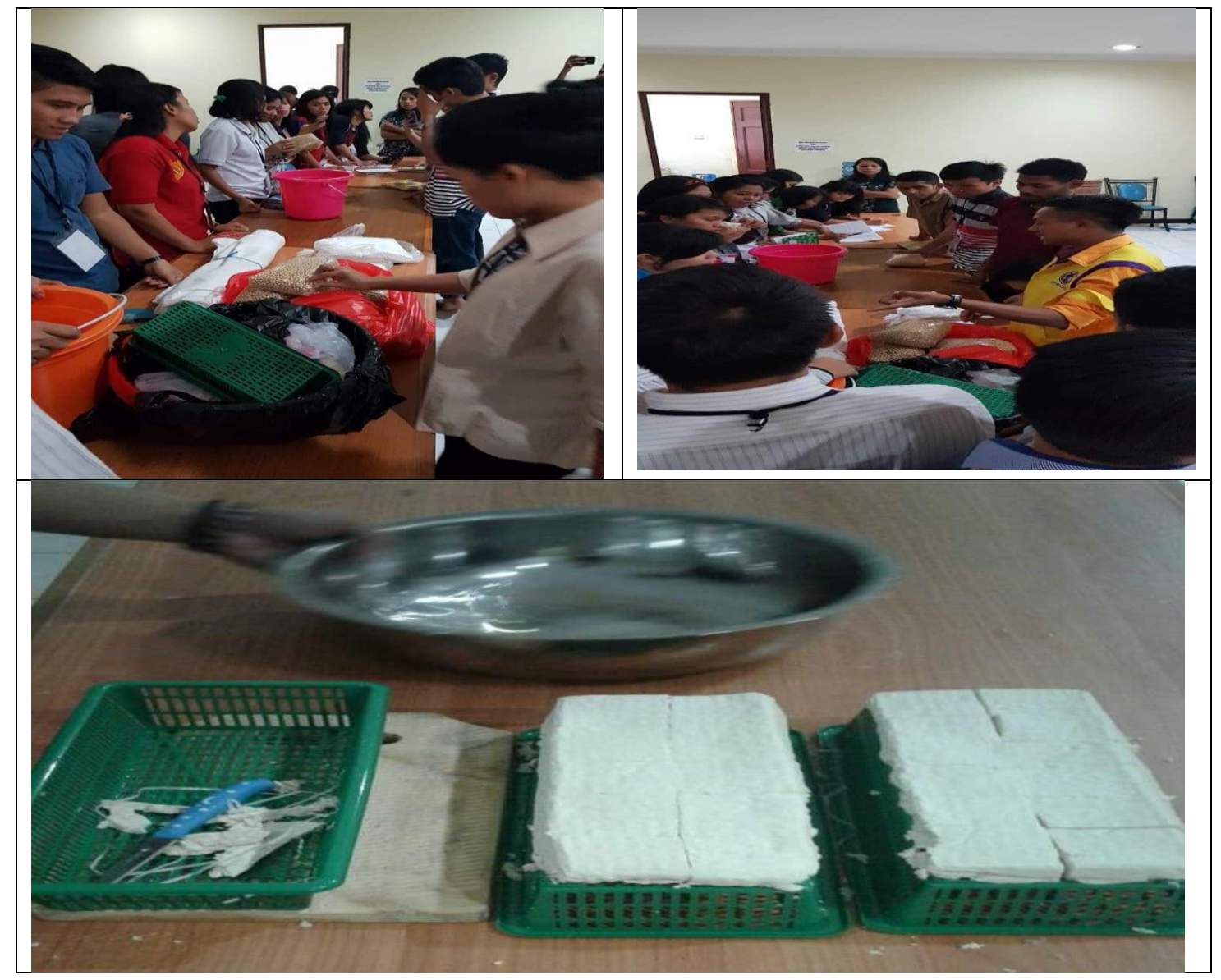

Gambar 3. Mahasiswa STT Real Batam Praktek Pembuatan Tahu \& Tempe

\section{Enterpreneurship sebagai Jembatan Dalam Memberitakan Injil}

Integrasi pendidikan Teologi dan Pendidikan kewirausahaan di sekolah teologi dapat dilaksanakan melalui tiga jalur, yaitu:

1. Pendidikan karakter yang terpadu dalam Pembelajaran

2. Pendidikan karakter yang terpadu dalam kegiatan Ekstra Kurikuler

3. Pendidikan karakter yang terpadu dalam kegiatan Pengembangan Diri

Jiwa entrepreneurship sebenarnya bukanlah hal yang tabu dalam Pendidikan teologi, Junior Natan Silalahi menuliskan juga bagaimana Paulus begitu mandiri yang tidak menghalangi dirinya dalam memberitakan Injil, sekaligus sebagai seorang entrepreneur. ${ }^{12}$ Jehidupan Paulus dalam perjalanan pelayanannya begitu unik, karena jiwa entrepreneurship yang dimilikinya, Paulus juga merasa terbantu secara mandiri untuk melakukan banyak perjalanan misi. Dalam hal pemberitaan Injil

${ }^{10}$ Bakti Widyaningrum, "Peran Guru Dalam Menanamkan Sikap Kewirausahaan Peserta Didik," in Seminar Nasional Dan Call For Papers ROUNDTABLE for INDONESIAN ENTREPRENEURSHIP EDUCATORS, ed. Heri Pratikto et al. (Malang: CV AMPUH MULTI REJEKI, 2016), 94-103.

${ }^{11}$ James O Fiet, "The Theoretical Side of Teaching Entrepreneurship," Journal of Business Venturing 16, no. 1 (2001): 1-24, https://econpapers.repec.org/RePEc:eee:jbvent:v:16:y:2001:i:1:p:1-24.

12 Junior Natan Silalahi, "PAULUS SANG ENTREPRENEUR: Pembuat Tenda Sebagai Jembatan Penginjilan," Visio Dei: Jurnal Teologi Kristen 1, no. 1 (2019): 1-18, http://jurnal.sttstarslub.ac.id/index.php/js/article/view/9. 
Paulus begitu maju, dalam hal kehidupan ia bukan hanya menjadi teladan tetapi memberikan contoh untuk orang-orang Kristen juga supaya tidak menjadi beban bagi siapapun.

Orang-oran Kristen kadang mengalami kesulitan Ketika memberitakan Injil secara frontal. Paulus memanfaatkan pekerjaan sebagai tukang tenda sebagai jembatan pewartaan Injil. Paulus lebih fleksibel berada dalam lingkaran orang-orang yang berkepentingan dengan pekerjaan Paulus. Dalam hal ini Paulus membangun sebuah hubungan melalui keterampilan yang ia kuasa.

Dalam hal Pendidikan entrepreneurship di sekolah teologi, selain daripada dapat dijadikan sarana untuk membangun hubungan dengan orang lain, pekerjaan membuat tahu dan tempe bisa berguna untuk self -support seperti: kebutuan protein nabati, kebutuhan untuk mencukupi keperluan gizi asrama, keahlian yang dapat berguna di ladang Misi, bahkan untu medapatkan penghasilan tambahan.

\section{SIMPULAN}

Kegiatan PkM Produksi tahu-tempe dapat terselenggarakan dengan baik dan berjalan dengan lancar, sesuai dengan rencana kegiatan yang telah disusun, tanpa ada kendala yang dihadapi. Kegiatan kegiatan ini menjadi salah satu kegiatan yang diekstrakurikulerkan. Ka.Prodi Teologi berkomitmen untuk menindaklanjuti kegiatan dengan melibatkan group-group Program Kreativitas Mahasiswa lain di Lingkungan kampus STT Real Batam. Hal ini di maksudkan untuk meningkatkan kualitas dan kuantitas kegiatan PKM di level mahasiswa. Kegiatan pengabdian masyarakat Kegiatan PKM ini akan dijadikan projek percontohohan kegiatan wirausaha guna eningkatkan partisipasi mahasiswa dalam mendukung kegiatan yang bersifat enterpreneur Institusi STT Real Batam.

Berdasarkan hasil dan pembahasan yang telah dipaparkan maka dapat ditarik kesimpulan sebagai berikut: 1) jiwa entrepreneurship begitu positif untuk dimiliki dan dikembangkan oleh mahasiswa teologi, 2) konsep entrepreneurship dapat menjadi jembatan yang efisien dalam pemberitaan Injil, 3) Keterampilan Pembuatan tahu-tempe berguna sebagai self-support, baik untuk keperluan protein nabati, kebutuhan gizi di asrama, keahlian yang sangat berguna di lading Misi, maupun untuk mendapatkan penghasilan tambahan.

\section{DAFTAR PUSTAKA}

Ememe, O N, S C Ezeh, and C A Ekemezie. "The Role of Head-Teacher in The Development of Entrepreneurship Education In Primary Schools." Journal of Social Sciences and Humanities 2, no. 1 (2013): $242-249$.

Fiet, James O. "The Theoretical Side of Teaching Entrepreneurship." Journal of Business Venturing 16, no. 1 (2001): 1-24. https://econpapers.repec.org/RePEc:eee:jbvent:v:16:y:2001:i:1:p:1-24.

Kuswara, Heri. "Strategi Perguruan Tinggi Mewujudkan Entrepreneurial Campus." Badan Riset Dan Inovasi Nasional Republik Indonesia. Jakarta, February 2012. brin.go.id/strategi-perguruantinggi-mewujudkan-entrepreneurial-campus/.

Ormrod, J. E. Human Learning. 3rd ed. Upper Saddle River, New Jersey: Merrill Prentice Hall, 1999.

Seikkula-Leino, Jaana, Elena Ruskovaara, Markku Ikavalko, Johanna Mattila, and Tiina Rytkola. "Promoting Entrepreneurship Education: The Role of the Teacher?" Education + Training 52, no. 2 (March 16, 2010): 117-127.

https://www.emerald.com/insight/content/doi/10.1108/00400911011027716/full/html.

Silalahi, Junior Natan. "PAULUS SANG ENTREPRENEUR: Pembuat Tenda Sebagai Jembatan Penginjilan." Visio Dei: Jurnal Teologi Kristen 1, no. 1 (2019): 1-18. http://jurnal.sttstarslub.ac.id/index.php/js/article/view/9.

Utami, Citra Perdani, Sukma Ayu Fitrianingrum, and Kristinah Haryani. "Pemanfaatan Iles-Iles (Amorphophallus Oncophylus) Sebagai Bahan Pengenyal Pada Pembuatan Tahu." Jurnal Teknologi Kimia dan Industri 1, no. 1 (2012): 79-85.

Wardoyo. "Pengaruh Pendidikan Dan Karakteristik Kewirausahaan Terhadap Intensi Berwirausaha Mahasiswa Pada Perguruan Tinggi Swasta Di Jakarta.” In Seminar Nasional Kewirausahaan Dan Inovasi Bisnis II 2012. Jakarta: Universitas Tarumanagara, 2012. 
Widyaningrum, Bakti. "Peran Guru Dalam Menanamkan Sikap Kewirausahaan Peserta Didik." In Seminar Nasional Dan Call For Papers ROUNDTABLE for INDONESIAN

ENTREPRENEURSHIP EDUCATORS, edited by Heri Pratikto, Sudarmiatin, Sutrisno, F.X. Danardana Murwani, and Nurika Restuningdyah, 94-103. Malang: CV AMPUH MULTI REJEKI, 2016.

Wijaya, Tony. "Kajian Model Empiris Perilaku Berwirausaha UKM DIY Dan Jawa Tengah." Jurnal Manajemen dan Kewirausahaan 10, no. 2 (2008): 93-104. 